\title{
Asplenium badinii (Aspleniaceae), a New Endemic Fern Species from Minas Gerais, Brazil
}

\author{
Lana S. Sylvestre* and Paulo G. Windisch \\ Departamento de Botânica, Universidade Federal Rural do Rio de Janeiro, BR-465 Km 7, \\ Seropédica, RJ 23890-000, Brazil. *Author for correspondence: lana@ufrrj.br
}

Abstract. A new species of Asplenium L. (Aspleniaceae) is described and illustrated. Asplenium badinii Sylvestre \& P. G. Windisch is an endemic species of the isolated forest clumps (capões) from Itacolomi State Park, from Minas Gerais, Brazil, in areas dominated by open rocky sites (campos rupestres). This environment is known for its high level of generic and specific endemism. The new species belongs to the A. salicifolium L. species group, with apical pinnae similar to lateral ones, smooth blades, and spores with echinate perispore. It is related to A. juglandifolium Lamark and A. bradeanum Handro. Diagnostic characters for $A$. badinii are the long basal segment on the acroscopic side of the proximal pinnae as well as the linear to linearlanceolate scales on the stem.

Resumo. Uma nova espécie de Asplenium L. é descrita e ilustrada. Asplenium badinii Sylvestre \& P. G. Windisch é uma espécie endêmica dos capões de mata do Parque Estadual do Itacolomi, no Estado de Minas Gerais, Brasil, em área dominada por campos rupestres. Este ambiente é reconhecido pela ocorrência de um grande número de espécies e gêneros endêmicos. Esta espécie pertence ao grupo de A. salicifolium L. Possui pina apical conforme, lâmina glabra e esporos com superfície espinhosa. É afim de A. juglandifolium Lamark e A. bradeanum Handro. Os caracteres diagnósticos são o longo segmento presente no lado acroscópico da porção proximal das pinas basais e as escamas do caule linear-lanceoladas.

Key words: Aspleniaceae, Asplenium, Brazil, ferns, IUCN Red List, Minas Gerais, Pteridophyta, spleenwort.

Brade (1942) estimated the occurrence of ca. 63 species of Asplenium L. in Brazil. Tryon and Tryon (1982) suggested that 50 species are concentrated in southeastern Brazil, an area that is considered one of the main centers of diversity of pteridophytes in the Neotropics. According to Sylvestre (2001), this family is represented in Brazil by two genera: Asplenium, with 69 species, and Antigramma C. Presl, with three species. These fern taxa grow mainly in humid and shaded forests with terrestrial, epipetric, and epiphytic habits (Sylvestre, 2001).

During work on the first author's Ph.D. thesis on the Brazilian species of the family Aspleniaceae, a new species was discovered. The new species occurs at the base of the Pico do Itacolomi, which lies between the municipalities of Ouro Preto and Mariana, in the Brazilian state of Minas Gerais, within Itacolomi State Park. This area is dominated by campos rupestres or rocky open grasslands sites at higher altitudes, where large rock formations present islands of wet forests in protected places called capões. The gallery forests, along streams, extend altitudinally upward and link with these usually isolated forest clumps. The capões, at higher altitudes, are influenced by atmospheric humidity and clouds. Notably, the flora of the campos rupestres is significantly composed of endemic elements, both at the generic and species levels (Giulietti et al., 1997). According to the List of Threatened Plants from Minas Gerais state (Mendonça \& Lins, 2000), two thirds of the threatened species of this state grow in the campos rupestres.

Asplenium badinii Sylvestre \& P. G. Windisch, sp. nov. TYPE: Brazil. Minas Gerais: Ouro Preto, base do Itacolomi, zona sul, mata sobre quartzito, Sep. 1972, J. Badini s.n. (holotype, OUPR 21429, photo at RBR). Figure 1.

Rhizoma erectum, paleaceum, paleis linearibus vel lineari-lanceolatis, castaneis, clathratis, $0.6-2.0 \mathrm{~cm}$ longis, $0.7-2.0 \mathrm{~mm}$ latis, attenuatis, unicostatis. Folium pinnatum, petiolo $8-23 \mathrm{~cm}$ longo, lamina $25-40 \mathrm{~cm}$ longa, $20-22 \mathrm{~cm}$ lata; pinnis 5- ad 7-jugis, longe attenuatis, integris, proximalibus acroscopicis cum segmento lanceolato acuto, apicalibus conformibus; venis plerumque 2 -furcatis, immersis. Sori lineares. Sporae echinatae.

Plants epipetric; roots fasciculate, covered by yellow-gold to brown hairs; stems erect, slightly curved on the apical portion, nonstoloniferous, apex densely covered by castaneous, clathrate, linear to linear-lanceolate scales $(0.6-2 \times 0.07-0.2 \mathrm{~cm})$, with truncate to cordiform base, apex long attenuate, unicostate. Leaves pinnate, erect, clumped (2 to 6 


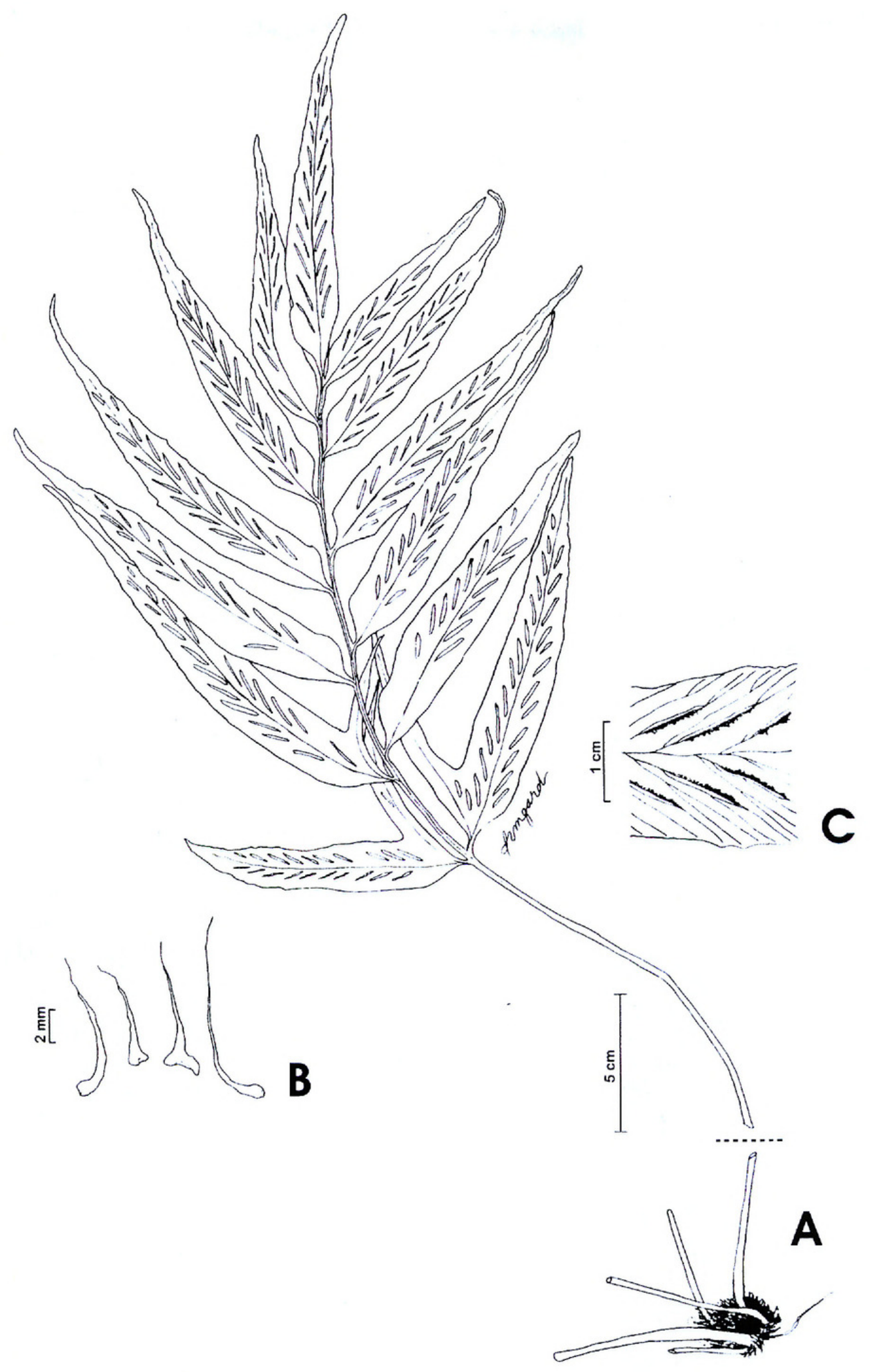

Figure 1. Asplenium badinii Sylvestre \& P. G. Windisch. - A. Habit. - B. Stem scales. —C. Section of fertile pinnae, showing 2-forked venation and sori. Drawn from the holotype, Badini s.n. (OUPR 21429).

leaves per plant); petiole long $(8-23 \mathrm{~cm})$, ca. $1 / 5-1 / 3$ the leaf length, straight to 1 -sulcate on the adaxial surface, dull, gray-green, ca. $0.3-0.5 \mathrm{~cm}$ wide proximally, narrowing to apex, glabrous, not winged; blade 1-pinnate, chartaceous, light green, ovate to lanceo- late, $25-40 \times 20-22 \mathrm{~cm}$, apex acute, not pinnatifid, base truncate; rachis green, glabrous, not winged; pinnae in 5 to 7 pairs, alternate, distant, long attenuate, falcate, petiolulate (petiolule ca. $1-2 \mathrm{~mm}$ ); apical pinnae longer than lateral ones, similar in shape, 
$12-14 \times 2-2.2 \mathrm{~cm}$, base unequal, entire or sometimes auriculate; medial pinnae lanceolate, base subequilateral to truncate on the acroscopic side; basal pinnae lanceolate, longer than the medial ones (14-17 $\times 2$ $2.8 \mathrm{~cm})$, base acroscopic, with lanceolate, acute segment, ca. 3-5 cm, generally overlapping the rachis abaxially, basiscopic side cuneate; veins immersed, free, twice forked, thickened at terminus; sori ca. 2 to 4 per $2 \mathrm{~cm}$ of the pinnae, linear along veins, ca. $1 / 2-2 / 3$ the length between costa and margin, straight to slightly curved, basal sori occasionally diplazioid; indusia linear, membranaceous, concolorous, margin entire. Spores with echinate perispore, spines with wide base and apex slightly curved.

Distribution and habitat. Asplenium badinii is endemic to humid areas in isolated forest clumps or capões in Itacolomi State Park in Minas Gerais, Brazil, where it grows on rocks covered by humus near streams and in shaded places, at $1300 \mathrm{~m}$ elevation.

IUCN Red List category. Asplenium badinii is classified as Critically Endangered (CR) according to IUCN Red List criteria (IUCN, 2001) because it is restricted to a small and threatened area, grows in isolated populations in specific habitats, and has not been collected since 1972. For these reasons, it is possible that the population is declining.
Etymology. The new species is named in honor of José Badini, professor at the Escola de Farmácia de Ouro Preto and collector of the type specimen.

Relationships. The new species is characterized by the long acroscopic segment on the basal pinnae, the immersed veins, the linear to linear-lanceolate stem scales, and the echinate perispore. It belongs to the Asplenium salicifolium L. group, especially by its echinate perispore and 1-pinnate leaf blade. Asplenium badinii is unique in having a lanceolate segment on the acroscopic side of the basal pinnae. Asplenium juglandifolium Lamark and A. bradeanum Handro differ by the absence of this segment on the pinnae. In addition, compared to A. badinii, A. juglandifolium and A. bradeanum have narrower stem scales (ca. $0.5 \mathrm{~mm}$ and $0.6-0.8 \mathrm{~mm}$, respectively). Asplenium badinii has been confused with $A$. oligophyllum Kaulfuss based on the habit, the 1-pinnate leaf, the similarly shaped apical pinnae, and the texture of the leaf blades. However, $A$. oligophyllum differs by its broader stem scales (4-13 $\times$ $2-3 \mathrm{~mm}$ ), the absence of a basal segment on the proximal pinnae, and its cristate perispore.

Paratypes. BRAZIL. Minas Gerais: Ouro Preto, Mata do Custódio, Sep. 1972, J. Badini s.n. (OUPR 21430), Sep. 1972, J. Badini s.n. (OUPR 21435), 1 Nov. 1970, J. Badini s.n. (OUPR 5910); base da Serra do Itacolomi, Lago do Manso, Feb. 1971, M. A. Lisboa s.n. (OUPR 4138).

Key to Brazilian Species of Asplenum with Erect Stems, l-Pinnate Leaf Blade, and Terminal. Pinnae Similar in Shape to Lateral. ONES

1a. Spores with echinate perispore.

2a. Acroscopic base of lateral pinnae with a round and obtuse auricle, usually overlapping the rachis; basiscopic side cuneate $\ldots \ldots \ldots \ldots \ldots \ldots \ldots \ldots \ldots \ldots \ldots \ldots \ldots \ldots \ldots \ldots \ldots \ldots \ldots \ldots \ldots \ldots \ldots \ldots \ldots$ salicifolium $\mathrm{L}$.

2b. Base of pinnae subequilateral or with an acute segment on acroscopic side.

3a. Pinnae 1 to $2(4)$ pairs. . . . . . . . . . pearcei Baker 3b. Pinnae 6 to 20 pairs.

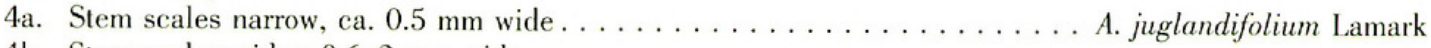

4b. Stem scales wider, $0.6-2 \mathrm{~mm}$ wide.

5a. Acroscopic segment on basal pinnae lanceolate, acute. . . A. badinii Sylvestre \& P. G. Windisch

5b. Basal pinnae without acroscopic segment. . . . . . . . . . bradeanum Handro

1b. Spores with cristate perispore.

6a. Indusia elliptic, vaulted, with curved margins, ca. $5-7 \mathrm{~mm} \operatorname{long} \ldots \ldots \ldots \ldots \ldots \ldots$ feei Kunze ex Fée

6b. Indusia linear, with straight margins, ca. $7-17 \mathrm{~mm}$ long.

7a. Acroscopic side of pinnae cuneate; stem scales ovate-lanceolate, wide, ca. 2-3 mm wide, light brown. . $\ldots \ldots \ldots \ldots \ldots \ldots \ldots \ldots \ldots \ldots \ldots \ldots \ldots \ldots \ldots \ldots \ldots \ldots \ldots \ldots \ldots$ oligophyllum Kaulfuss

7b. Pinnae bases with rounded segments (rarely lanceolate), bilateral; stem scales lanceolate, narrow, ca.

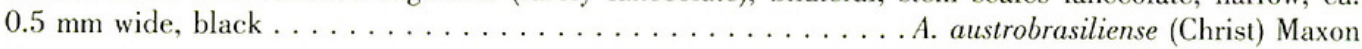

Acknowledgments. We thank Miriam B. Roschel for her help with fieldwork in the Itacolomi area and Irmgard Schanner for the drawing. We are grateful to the curator of the herbarium of Pharmacy School of the Universidade Federal de Ouro Preto (OUPR) for loans of specimens. This work was funded by CAPES Foundation and the National Council for Scientific and Technological Development (CNPq) in Brazil.
Literature Cited

Brade, A. C. 1942. A composição da flora pteridófita do Itatiaia. Contribuição à fitogeografia dessa região. Rodriguesia 15: 29-43.

Giulietti, A. M., J. R. Pirani \& R. M. Harley. 1997. Espinhaço range region. Pp. 397-404 in V. H. Heywood \& D. S. Davis (editors), Centers of Plant Diversity - A Guide and Strategy for Their Conservation, Vol. 3: The Americas. World Wildlife Fund/International Union for Conservation of Nature, Cambridge. 
IUCN. 2001. IUCN Red List Categories and Criteria, Version 3.1. Prepared by the IUCN Species Survival Comission. IUCN, Gland, Switzerland, and Cambridge, United Kingdom.

Mendonça, M. P. \& L. V. Lins. 2000. Lista Vermelha das Espécies Ameaçadas de Extinção da Flora de Minas Gerais. Fundação Biodiversitas, Belo Horizonte.
Sylvestre, L. S. 2001. Revisão Taxonômica das Espécies da Família Aspleniaceae A. B. Frank Ocorrentes no Brasil. Tese de Doutorado, Instituto de Biociências, Universidade de São Paulo.

Tryon, R. M. \& A. F. Tryon. 1982. Fern and Allied Plants with Special Reference to Tropical America. SpringerVerlag, New York. 


\section{$2 \mathrm{BHL}$ Biodiversity Heritage Library}

Sylvestre, Lana da Silva. 2008. "Asplenium badinii (Aspleniaceae), a new endemic fern species from Minas Gerais, Brazil." Novon a journal of botanical nomenclature from the Missouri Botanical Garden 18, 538-541.

View This Item Online: https://www.biodiversitylibrary.org/item/55381

Permalink: https://www.biodiversitylibrary.org/partpdf/58021

\section{Holding Institution}

Missouri Botanical Garden, Peter H. Raven Library

\section{Sponsored by}

Missouri Botanical Garden

\section{Copyright \& Reuse}

Copyright Status: In copyright. Digitized with the permission of the rights holder.

License: http://creativecommons.org/licenses/by-nc-sa/3.0/

Rights: https://biodiversitylibrary.org/permissions

This document was created from content at the Biodiversity Heritage Library, the world's largest open access digital library for biodiversity literature and archives. Visit BHL at https://www.biodiversitylibrary.org. 